\title{
Phantom limbs as reported by S. Weir Mitchell
}

\author{
Morton Nathanson, MD
}

Descriptions of the phenomenon of phantom limbs by S. Weir Mitchell appeared in two lay periodicals before being published for the medical profession..$^{1-3}$

S. Weir Mitchell (1829-1914), neurologist extraordinaire, one of the fathers of American neurology and respected popular literary figure of his time, is credited with the first careful clinical investigation and explanation of what he referred to as the "phantom limb."4 Mitchell acknowledged that "the feelings and delusions of men who had lost members have often been the subjects of casual notice in surgical treatises from as far back as Ambrose Paré's time." 2

Mitchell's initial description was published anonymously in the Atlantic Monthly in 1866 (figure 1) as a story entitled "The Case of George Dedlow." It was an account written in the first person by a fictional army physician who, after a series of severe injuries, eventually had all his limbs amputated for a variety of reasons. Most of Dedlow's behavior, hallucinations, and delusions relating to his absent limbs were based on the verbalizations and reactions of Mitchell's own patients. These patients were cared for in the "Stump Hospital," Philadelphia, devoted to hundreds of amputees from the Civil War. Much of Mitchell's writing for the lay reader (novels, short stories, and poetry) was sprinkled with his experiences from casualties during and after that war.

In relation to Dedlow's initial wound involving his right arm before amputation, Mitchell described the symptoms of causalgia: "I felt as if the hand was caught and pinched in a red-hot vice... at length the pain became absolutely unendurable, and... I screamed, cried, and yelled in my torture, until, as I suppose, my captors became alarmed, and, stopping, gave me a handkerchief,-my own, I fancy,- and a canteen of water, with which I wetted the hand, to my unspeakable relief." Following the amputation of the right arm near the shoulder joint, "I said, pointing to the arm which lay on the floor: 'There is the pain, and here am I. How queer!" "

Upon awakening after both lower limbs were amputated, Dedlow said, "I got hold of my own identity in a moment or two, and was suddenly aware of a sharp cramp in my left leg. I tried to get at it to rub it with my single arm, but, finding myself too weak, hailed an

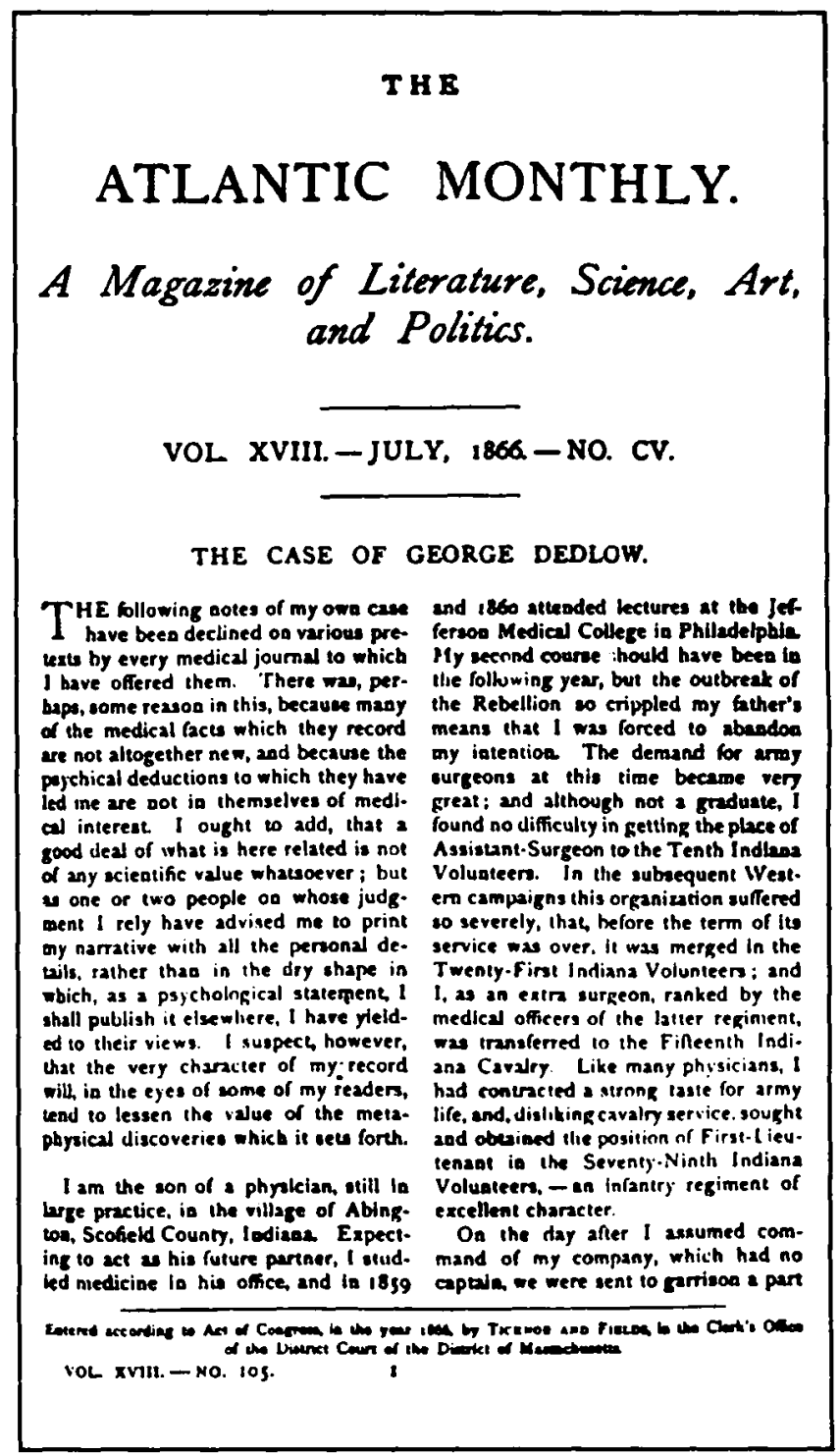

Figure 1. First page of S.W. Mitchell's anonymous report of 1866. Note opening sentence.

attendant. 'Just rub my left calf, ... if you please.' 'Calf? ... You ain't none, pardner. It's took off.' 'I know better,... I have pain in both legs.' 'Wall, I

From the Department of Neurology, Long Island Jewish Medical Center Campus of SUNY-Stony Brook, School of Medicine, New Hyde Park, NY.

Received February 13, 1987. Accepted for publication in final form March 23, 1987.

Address correspondence and reprint requests to Dr. Nathanson, Department of Neurology, Long Island Jewish Medical Center Campus of SUNY --Stony Brook, School of Medicine. New Hyde Park, NY 11042. 


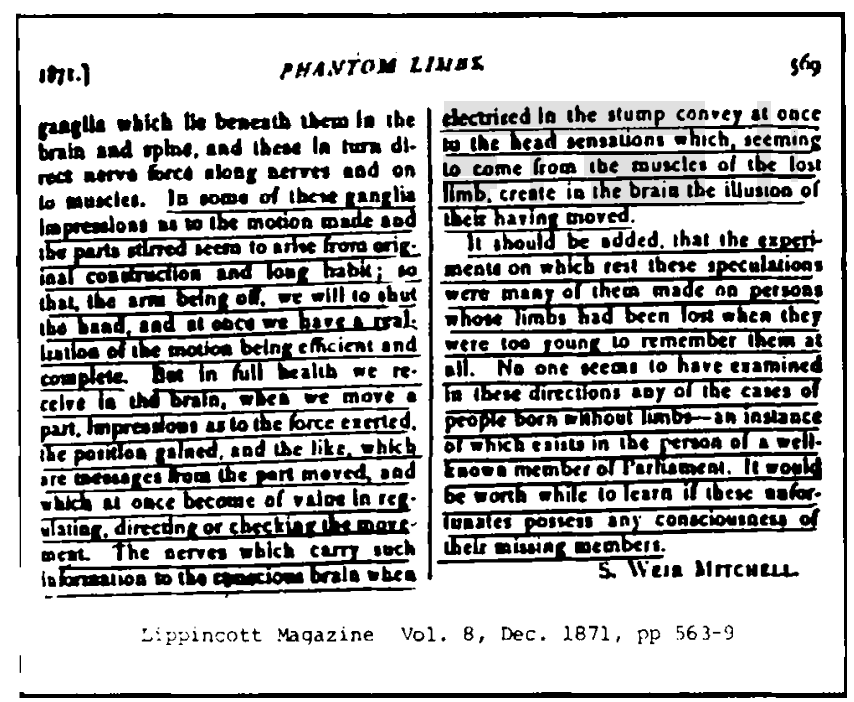

Figure 2. Last page of "Phantom Limbs," S.W. Mitchell's second report in a lay periodical, 1871, with partial explanation of the phantom phenomenon and author's name at the end.

never!... You ain't got nary leg.' As I did not believe him, he threw off the covers, and, to my horror, showed me that I had suffered amputation of both thighs, very high up."

After spending a number of months in the Stump Hospital, "I amused myself . . . by noting in my mind all that I could learn from other limbless folk, and from myself, as to the peculiar feelings which were noticed in regard to lost members..... [They] for many months felt the usual consciousness that they still had the lost limb. It itched or pained, or was cramped.... . If they had painful sensations referred to it, the conviction of its existence continued unaltered for long periods."

Dedlow continues by theorizing (through the "anonymous author") that the sensation "passes up the nerves towards the centres, and occasions a more or less constant irritation of the nerve-fibres, producing neuralgia, which is usually referred to that part of the lost limb to which the affected nerve belongs. This pain keeps the brain ever mindful of the missing part, and, imperfectly at least preserves to the man a consciousness of possessing that which he has not."

At the end of this story Dr. Mitchell indirectly spoofs the spiritualists. Dedlow was taken to a seance and there, when the medium contacted two spirits and recited, "United States Army Medical Museum Numbers 3486,3487 ," he responded, "'Good gracious, they are my legs, my legs.' A strange wonder filled me and, to the amusement of everyone, I rose, and, staggering a little, walked across the room on limbs invisible to them or me."

In December 1871 an article appeared in the Lippincott Magazine, another lay periodical, this time under Mitchell's name, entitled "Phantom Limbs"' (figure 2). Here he reported the phenomenon in more detailed and scientific terms, based again on the descriptions of his amputees. In it he referred to that 1866 article in the Atlantic Monthly as "purported to be the autobiography of an officer who survives the loss of all his limbs." Mitchell still did not let on that he had been the author.

Experiments with the electric current on the nerves of motion in the stump are most instructive. If, for example, we pass an interrupted current through these nerves, we cause sensations referred to the lost limb, but we seem also to produce muscular movement in it... . [I]n full health we receive in the brain, when we move a part, impressions as to the force exerted, the position gained, and the like, which are messages from the part moved, and which at once become of value in regulating, directing or checking the movement. The nerves which carry such information to the conscious brain when electrized in the stump convey at once to the head sensations which, seeming to come from the muscles of the lost limb, create in the brain the illusion of their having moved.

This was one of the rare instances in which a medical scientist reported observations in a lay periodical of a phenomenon heretofore not appearing in any professional journal.

Finally, in 1872 in his book, Injuries of the Nerves and Their Consequences, ${ }^{3}$ under the chapter heading "Neural Maladies of Stumps," he described for the medical profession the phenomenon of phantom limbs and discussed it in much more detail, giving many case examples that included not only the physiology of the stump and the sensory hallucinations related to the absent limbs (pain, itching, position, size, and movement), but also his investigations by faradization of "the nerves in or above the stump ... [that] cause the lost fingers and thumb to seem to be flexed or extended ... [and the sensation that] the hand is bent and

The reason for choosing anonymity in his initial publication was not made clear by Mitchell except indirectly. The opening sentence of "The Case of George Dedlow" reads: "The following notes of my own case have been declined on various pretexts by every medical journal to which I have offered them."' In DeJong's History of American Neurology ${ }^{5}$ it is suggested that "The Case of George Dedlow" was submitted without Mitchell's knowledge. But one can safely speculate that the indelicate nature of the subject matter, plus Mitchell's flair for storytelling as indicated by his subsequent prolific literary output, may have been his motivation for anonymity.

\section{References}

1. Anonymous. The case of George Dedlow. The Atlantic Monthly Boston: Ticknor and Fields. July 1866, vol. XVIII, no. 105, pp. 1-11.

2. Mitchell SW. Phantom limbs. Philadelphia: The Lippincott Magazine, Dec. 1871;8:563-569.

3. Mitchell SW. Injuries of nerves and their consequences. Reproduction, unaltered, of original by J.P. Lippincott, 1872. New York Dover Publications, 1965:342-368.

4. Schilder $P$. The image and appearance of the human body. London Kegan, Paul, Trench, and Trubner \& Co., 1935:63.

5. DeJong RN. A history of American neurology. New York: Raven Press, 1982:20. 


\title{
Neurology
}

\author{
Phantom limbs as reported by S. Weir Mitchell \\ Morton Nathanson \\ Neurology 1988;38;504 \\ DOI 10.1212/WNL.38.3.504
}

This information is current as of March 1, 1988

\section{Updated Information \& \\ Services}

Citations

Permissions \& Licensing

Reprints including high resolution figures, can be found at: http://n.neurology.org/content/38/3/504.citation.full

This article has been cited by 1 HighWire-hosted articles: http://n.neurology.org/content/38/3/504.citation.full\#\#otherart icles

Information about reproducing this article in parts (figures,tables) or in its entirety can be found online at: http://www.neurology.org/about/about_the_journal\#permissio ns

Information about ordering reprints can be found online: http://n.neurology.org/subscribers/advertise

Neurology @ is the official journal of the American Academy of Neurology. Published continuously since 1951 , it is now a weekly with 48 issues per year. Copyright $(\subseteq) 1988$ by Edgell

Communications, Inc.. All rights reserved. Print ISSN: 0028-3878. Online ISSN: 1526-632X.

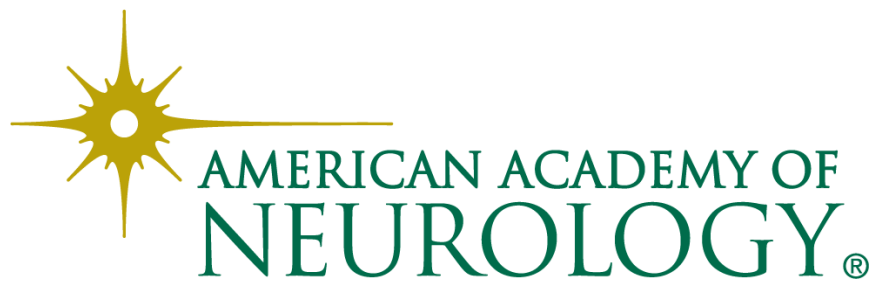

